\title{
COMPARATIVE STUDY : DETERMINANT ON BANKING PROFITABILITY BETWEEN BUKU 4 AND BUKU 3 BANK IN INDONESIA
}

\author{
Andy Setiawan ${ }^{1}$ dan Bambang Hermanto ${ }^{2}$ \\ ${ }^{1}$ LP3I Polytechnics Jakarta \\ ${ }^{2}$ LP3I Polytechnics Jakarta \\ Email : ${ }^{1}$ andysetiawan2285@gmail.com, ${ }^{2}$ bb.hermanto@yahoo.com
}

\begin{abstract}
This research is performed on order to analyze the influence of Non Performing Loan (NPL), Loan to Deposit Ratio (LDR), Capital Adequacy Ratio (CAR), Net Interest Margin (NIM), and Operating Expense to Operating Income Ratio (OEOI) as independent variable toward Return on Asset (ROA) and Return on Equity (ROE) as dependent variable. Sample for this research is all of BUKU 4 banks and seven banks on BUKU 3 banks in Indonesia in 2006-2015 period. Data analysis with multi liniear regression. The result of this research shows that all of independent variables have significant influence on ROA and ROE simultaneously. NIM has partially significant effect on profitability both in BUKU 3 and BUKU 4 banks but other variables have various effect on profitability. The amount of the contribution or influence independent variables to ROA are $64,7 \%$ in BUKU 3 banks and 90,4\% on BUKU 4 banks. Meanwhile contribution of independent variables to ROE are 55,4\% in BUKU 3 banks and 74,1\% in BUKU 4 banks.
\end{abstract}

Keywords: Banking, Profitability, BUKU 3, BUKU 4

\begin{abstract}
Abstrak: Penelitian ini dilakukan untuk menganalisis pengaruh variabel independen Non Performing Loan (NPL), Loan to Deposit Ratio (LDR), Capital Adequacy Ratio (CAR), Net Interest Margin (NIM), dan Operating Expense to Operating Income (OEOI) terhadap variabel dependen Return On Asset (ROA) dan Return on Equity (ROE). Sampel yang digunakan adalah seluruh bank BUKU 4 dan tujuh bank BUKU 3 di Indonesia selama periode 2006-2015. Teknik analisis data yang digunakan adalah regresi linier berganda. Hasil penelitian ini menunjukkan bahwa seluruh variabel independen berpengaruh signifikan secara bersama terhadap ROA dan ROE. Secara parsial NIM berpengaruh signifikan terhadap ROA dan ROE di BUKU 3 dan BUKU 4, sedangkan variabel lainnya memiliki pengaruh yang berbeda-beda terhadap profitabilitas. Kemampuan prediksi dari variabel independen tersebut terhadap ROA adalah 64,7\% di bank BUKU 3 dan 90,4\% di bank BUKU 4. Sedangkan variabel independen memiliki kemampuan prediksi terhadap ROE sebesar 55,4\% di bank BUKU 3 dan 74,1\% di bank BUKU 4.
\end{abstract}

Kata Kunci: Banking, Profitability, BUKU 3, BUKU 4

\section{INTRODUCTION}

Bank is an institution that plays an important role in the economy of a country. Bank is generally based on Law No. 10/1998 on banking, defines bank as a business that gathers fund from society in the form of savings and distributes the fund to the society in the form of credits and/or others in order to improve people's standard of living. Because of its central role the banking performance in a country have a major impact for the economy. In Indonesia there is clasification on bank based on the core capital of the bank. According to Bank Indonesia regulation number 14/26/PBI/2012 about the business activities and office network based on core capital of the Bank, the grouping of banks based on Commercial Bank Group of Business Activities (BUKU). 
Banks' BUKU categories:

1. BUKU 1 - banks with total core capital less than IDR 1 trillion. The business activities for banks classified into BUKU 1 are mainly limited to basic funding and borrowing and other banking services in Rupiah. The foreign exchange transaction is limited to the money changer activities.

2. BUKU 2 - banks with total core capital between IDR 1 trillion to IDR 5 trillion. The business activities for banks classified into BUKU 2 are broarder compared to banks classified into BUKU 1 and not limited to services in Rupiah. The banks classified into BUKU 2 can also enter into spot and other plain vanilla derivatives. The equity investment is limited to domestic financial institution with maximum of $15 \%$ ownership.

3. BUKU 3 - banks with total core capital between IDR 5 trillion to IDR 30 trillion. The banks classified under BUKU 3 can enter into all banking activities. The equity investment is limited to domestic financial institutions or other financial institutions incorporated in Asia countries with maximum of $25 \%$ ownership.

4. BUKU 4 - banks with total core capital above IDR 30 trillion. The banks can enter into domestic or off-shore equity investment with maximum of $35 \%$ of ownership.

Indonesian Commercial Banking profits grew negative $2.29 \%$ in 2016 first quarter, from IDR 29,63 trillion in the first quarter 2015 being only IDR 28,95 trillion in 2016. In fact, the ratio of net interest margin (NIM) banking experienced growth of $5.3 \%$ to $5.55 \%$. Based on Indonesian Banking Statistic released by the Financial Services Authority (OJK), negative banking profit growth driven by the increase in non interest expenses as much as $37.5 \%$ from IDR 92,51 trillion to IDR 127,21 trillion. While interest income increased just $6.74 \%$ to IDR 168,5 trillion and net interest income grew $13.75 \%$ from IDR 72,13 trillion in 2015 to IDR 82,05 trillion in 2016. The contribution to profit from BUKU 2 most negative with declining $41.48 \%$ to IDR 3,01 trillion. Followed by BUKU 1 group profit loss $9.09 \%$ to IDR 600 billion and group BUKU 4 down thin $2.46 \%$ to IDR 17,67 trillion from IDR 18,12 trillion previously. As for the bank BUKU 3 Group registered a profit growth of $34.6 \%$ of IDR 5,41 trillion in the first quarter 2015 to IDR 7,29 trillion in first quarter 2016. This research is performed on order to analyze determinant on banking profitability between BUKU 4 and BUKU 3 bank in Indonesia.

\section{LITERATURE REVIEW}

\section{Profitability}

The main purpose of banks, reaching the maximum level of profitability inconducting its operational activities (Buchory, 2015). Profitability describes the company's ability to profit through all the capabilities of existing sources (Harahap, 2015). There are some indicators to measure bank profitability. Return on Asset (ROA) is a financial ratio that indicates the profitability of a bank. It is a ratio of Income to its total asset (Khrawish, 2011). It measures the ability of the bank management to generate income by utilizing company assets at their disposal. In other words, it shows how efficiently the resources of the company are used to generate the income. It further indicates the efficiency of the management of a company in generating net income from all the resources of the institution (Khrawish, 2011). Based on Bank Indonesia regulation, adequate ROA is above 1,25\%. ROA will be used as a guide in measuring the profitability of banks by the Bank Indonesia as a banking supervisor, because ROA is an objective measurement method that is based on the data available to the bank about how banks have been managing the assets of the funds come from the public (Buchory, 2015). $\mathrm{ROE}$ is another financial ratio that refers to how much profit a company earned compared to the total amount of shareholder equity invested or found on the balance sheet. ROE is what the shareholders look in return for 
their investment. A business that has a high return on equity is more likely to be one that is capable of generating cash internally. Thus, the higher the ROE the better the company is in terms of profit generation (Ongore \& Kusa, 2013). It is further explained by Khrawish (2011) that ROE is the ratio of Net Income after Taxes divided by Total Equity Capital.

\section{Determinant on Bank Profitability}

The profitability of the bank can be influenced by a variety of factors such as Non Performing Loan (NPL), Loan to Deposit Ratio (LDR), Capital Adequacy Ratio (CAR), Net Interest Margin (NIM), and Operating Expense to Operating Income Ratio (OEOI). Credit is the greatest asset investment and the largest source of revenue for banks. If the credit fails then the ability of banks to provide new loans will be limited (Buchory, 2015). Besides bank revenue derived from loan interest will decrease and banks should establish loan loss reserves and finally will reduce the bank's profitability. Credit risk or credit quality of a bank is indicated by the Non Performing Loans (NPLs). Thus, NPLs can be used to measure the ability of banks to cover the risk of default of loan repayment by the debtor (Buchory, 2015). The indicators commonly used to measure the extent of intermediation by the banking system has been implemented is the ratio of Loans to Deposits Ratio (LDR). The higher this ratio is, the better it means that the bank could carry out intermediation function optimally. Vice versa, the lower this ratio means the bank in carrying out its intermediary function is not optimal (Buchory, 2015).

Adequate capital was regarded as the amount of capital that can effectively discharge the primary capital function of preventing bank failure by absorbing losses. Adequate capital will provide the ultimate protection against insolvency and liquidation arising from the risk in banking business (Adeyinka \& Olalekan, 2013)capital adequacy plays a key role in the determination of profitability. It was discovered that capitalization and profitability are indicators of bank risk management efficiency and cushion against losses not covered by current earnings (Adeyinka \& Olalekan, 2013. Adequate Capital can be measures by Capital Adequacy Ratio (CAR). Net Interest Margin (NIM) measures a bank's net interest spread and is defined as net interest income to total assets. Net interest margin is focused on the profit earned on interest activities and is an important measure of bank efficiency (Alper \& Anbar, 2011)the results show that asset size and non-interest income have a positive and significant effect on bank profitability. However, size of credit portfolio and loans under follow-up have a negative and significant impact on bank profitability. With regard to macroeconomic variables, only the real interest rate affects the performance of banks positively. These results suggest that banks can improve their profitability through increasing bank size and non-interest income, decreasing credit/asset ratio. In addition, higher real interest rate can lead to higher bank profitability (Alper \& Anbar, 2011). Operational efficiency is essential for banks to increase the rate of profit to be achieved one ratio that is commonly used to measure the level of bank efficiency is the ratio of operating expenses to operational income (OEOI) in the same period (Buchory, 2015).

This study aims to analyze NPL, LDR, CAR, NIM and OEOI ratio toward the banking profitability (ROA and ROE). In this research, sample that used is all banks in group BUKU 3 and BUKU 4 in Indonesia from 2006 to 2015 period. This study is focused to the bank group BUKU 3 and BUKU 4 banks because of the magnitude of the market share that was owned by the bank group. Total third party fund that was owned by this groups is more than IDR 3.200 trillion or approximately $80 \%$ from total third party fund in all commercial banks in Indonesia. The conclusion that can be drawn is that if BUKU 3 and BUKU 4 banks experiencing problems, then it will give a huge impact to the entire bank in Indonesia. 
In addition, these banks as an indicator of the level of health and performance of other commercial banks

\section{HYPOTHESES DEVELOPMENT}

According previous research result shows that Non Performing Loan (NPL) has negative and significant effect to bank profitability (Akhtar, Ali, \& Sadaqat, 2011; Eng, 2013; Ongore \& Kusa, 2013; Rotinsulu, Kindangen, \& Pandowo, 2015; Sabir, Ali, \& Habbe, 2012)the authors used linear multiple regression model and Generalized Least Square on panel data to estimate the parameters. The findings showed that bank specific factors significantly affect the performance of commercial banks in Kenya, except for liquidity variable. But the overall effect of macroeconomic variables was inconclusive at 5\% significance level. The moderating role of ownership identity on the financial performance of commercial banks was insignificant. Thus, it can be concluded that the financial performance of commercial banks in Kenya is driven mainly by board and management decisions, while macroeconomic factors have insignificant contribution. 1. Introduction Commercial banks play a vital role in the economic resource allocation of countries. They channel funds from depositors to investors continuously. They can do so, if they generate necessary income to cover their operational cost they incur in the due course. In other words for sustainable intermediation function, banks need to be profitable. Beyond the intermediation function, the financial performance of banks has critical implications for economic growth of countries. Good financial performance rewards the shareholders for their investment. This, in turn, encourages additional investment and brings about economic growth. On the other hand, poor banking performance can lead to banking failure and crisis which have negative repercussions on the economic growth. Thus, financial performance analysis of commercial banks has been of great interest to academic research since the Great Depression Intern the 1940's. In the last two decades studies have shown that commercial banks in SubSaharan Africa (SSA. While according the research of Buchory (2015), Suhardi and Darus Altin (2013) NPL has no significant effect to profitability. LDR has positive and significant effect to profitability according to (Ongore \& Kusa, 2013; Valentina Flamini, Calvin McDonald, 2013)the authors used linear multiple regression model and Generalized Least Square on panel data to estimate the parameters. The findings showed that bank specific factors significantly affect the performance of commercial banks in Kenya, except for liquidity variable. But the overall effect of macroeconomic variables was inconclusive at 5\% significance level. The moderating role of ownership identity on the financial performance of commercial banks was insignificant. Thus, it can be concluded that the financial performance of commercial banks in Kenya is driven mainly by board and management decisions, while macroeconomic factors have insignificant contribution. 1 . Introduction Commercial banks play a vital role in the economic resource allocation of countries. They channel funds from depositors to investors continuously. They can do so, if they generate necessary income to cover their operational cost they incur in the due course. In other words for sustainable intermediation function, banks need to be profitable. Beyond the intermediation function, the financial performance of banks has critical implications for economic growth of countries. Good financial performance rewards the shareholders for their investment. This, in turn, encourages additional investment and brings about economic growth. On the other hand, poor banking performance can lead to banking failure and crisis which have negative repercussions on the economic growth. Thus, financial performance analysis of commercial banks has been of great interest to academic research since the Great Depression Intern the 1940's. In the last two decades studies have shown that commercial banks in Sub-Saharan 
Africa (SSA and Alamsah (2013). Meanwhile other researcher shows that LDR has not significant effect to profitability (Almadany, 2012; Buchory, 2015). Some research results that CAR has positive and significant effect to profitability (Adeyinka \& Olalekan, 2013; Ongore \& Kusa, 2013; Sabir et al., 2012)capital adequacy plays a key role in the determination of profitability. It was discovered that capitalization and profitability are indicators of bank risk management efficiency and cushion against losses not covered by current earnings. Studies on moderating effect of ownership structure on bank performance are scanty. To fill this glaring gap in this vital area of study, the authors used linear multiple regression model and Generalized Least Square on panel data to estimate the parameters. The findings showed that bank specific factors significantly affect the performance of commercial banks in Kenya, except for liquidity variable. But the overall effect of macroeconomic variables was inconclusive at 5\% significance level. The moderating role of ownership identity on the financial performance of commercial banks was insignificant. Thus, it can be concluded that the financial performance of commercial banks in Kenya is driven mainly by board and management decisions, while macroeconomic factors have insignificant contribution. 1. Introduction Commercial banks play a vital role in the economic resource allocation of countries. They channel funds from depositors to investors continuously. They can do so, if they generate necessary income to cover their operational cost they incur in the due course. In other words for sustainable intermediation function, banks need to be profitable. Beyond the intermediation function, the financial performance of banks has critical implications for economic growth of countries. Good financial performance rewards the shareholders for their investment. This, in turn, encourages additional investment and brings about economic growth. On the other hand, poor banking performance can lead to banking failure and crisis which have negative repercussions on the economic growth. Thus, financial performance analysis of commercial banks has been of great interest to academic research since the Great Depression Intern the 1940's. In the last two decades studies have shown that commercial banks in Sub-Saharan Africa (SSA. While according Alper \& Anbar, 2011; Eng, 2013; Rotinsulu et al., 2015the results show that asset size and non-interest income have a positive and significant effect on bank profitability. However, size of credit portfolio and loans under follow-up have a negative and significant impact on bank profitability. With regard to macroeconomic variables, only the real interest rate affects the performance of banks positively. These results suggest that banks can improve their profitability through increasing bank size and non-interest income, decreasing credit/asset ratio. In addition, higher real interest rate can lead to higher bank profitability.Pengaruh NIM, BOPO, LDR, NPL \& CAR Terhadap ROA Bank Internasional dan Bank Nasional Go Public Periode 2007-2011 (Alper \& Anbar, 2011; Eng, 2013; Rotinsulu et al., 2015) shows that CAR has no significant effect toward profitability.

Earlier studies on NIM as a determinant on profitability of bank revealed that NIM has positive and significant effect (Sabir et.al, 2012; Eng, 2013). On the other hand, Almadany (2012), Alper and Anbar (2011) shows that there is no significant effect NIM toward profitability.According to some previous research results stated that OEOI has a negative and significant effect on bank profitability (Buchory, 2015; Haryanto, 2016). While the result of another study stated that OEOI has no significant effect to profitability (Sabir et.al, 2012; Eng, 2013). Based on previous research, hypotheses can be formulated as follows :
$\mathrm{H}_{1}$ : Non Performing Loans (NPL) is negative and significant effect to Profitability
$\mathrm{H}_{2}$ : Loan to Deposit Ratio (LDR) is positive and significant effect to Profitability


$\mathrm{H}_{3}$ : Capital Adequacy Ratio (CAR) is positive and significant effect to Profitability

$\mathrm{H}_{4}$ : Net Interest Margin (NIM) is positive and significant effect to Profitability

$\mathrm{H}_{5}$ : Operating Expense to Operating Income Ratio (OEOI) is negative and significant effect to Profitability

$\mathrm{H}_{6}$ : NPL, LDR, CAR, NIM, OEOI have significant effect to Profitability simultaneously

\section{METHOD}

The methods used in this research are descriptive method and verification method. Descriptive method is a method used to analyze data in a way to describe the data that has been collected as is without intending to apply general conclusions or generalizations while the verification method is a method of research that aims to determine the relationship between the independent variables (Buchory, 2015), namely NPL, LDR, CAR, NIM and OEOI to the dependent variable is the banking profitability as measured by the ROA and ROE.

Data used in this study is secondary data Indonesian banks on group BUKU 3 and BUKU 4 which include NPL, LDR, CAR, NIM, OEOI, ROA and the ROE were obtained from the Indonesian Banking Statistics, Financial Service Authority (OJK), Bank Indonesia (BI) and Indonesian Capital Market Directory (ICMD). The research sample was four banks from BUKU 4 group and seven banks on BUKU 3 group serve as the object of study. While the object is observed financial statements position as of December 31, 2006 to December 31, 2015.

The data analysis technique used in this study is a multiple linear regression. Data processing is done by using the software Smartpls version 2.0. PLS can be applied to model multiple regression and path analysis using observed variables. As it is known that the model estimation Ordinary Least Square (OLS) requires the classic linear assumptions in order to satisfy give BLUE (Best Linear Unbiased Estimates). If the sample data we have is small, there is a missing value, and there is multicollinearity problems, then the results of OLS estimation becomes unstable and increase the standard error of the coefficient being estimated. Analysis of multiple regression and path analysis for the variable observed using the PLS can solve this problem. The purpose of this analysis is to produce a model that transforms a set of mutually eksplanatori variables correlated into a set of new variables that are not mutually correlated. The trick is to make one indicator of latent variables for the formative-shaped (Latan, H., \& Ghozali, I, 2012).

The regression equation used is as follows:

$\begin{array}{ll}\text { Where } & : \\ \text { ROA } & : \text { Return on Asset } \\ \text { ROE } & : \text { Return on Equity } \\ \beta & : \text { Coefficient of the regression line } \\ \text { NPL } & : \text { Non Performing Loan } \\ \text { LDR } & : \text { Loan to Deposit Ratio } \\ \text { CAR } & : \text { Capital Adequacy Ratio } \\ \text { NIM } & : \text { Net Interest Margin } \\ \text { OEOI } & : \text { Operating Expense to Operating } \\ & \text { Income } \\ \varepsilon & : \text { Residual }\end{array}$

\section{RESULT AND DISCUSSION}

\section{Descriptive Statistic}

The basic descriptive statistic of the variables are presented in Table 1 and 2. For each variable, table 1 and 2 shows mean, minimum, maximum and standard deviation. On average, BUKU 3 banks, have a ROA $2,09 \%$ and ROE $14,68 \%$ over entire time period 2006 to 2015. When the mean of NPL is $2,53 \%$ and minimum value is $0,50 \%$ and maximum 7,95\%. Average of LDR and CAR are approximately $88 \%$ and $17,71 \%$ respectively. Meanwhile for NIM and OEOI are $6,89 \%$ and $75,22 \%$ on average for BUKU 3 banks. 
Table 1. Descriptive Statistic BUKU 3

\begin{tabular}{|c|c|c|c|c|c|}
\hline & $\mathbf{N}$ & Minimum & Maximum & Mean & Std. Deviation \\
\hline NPL_BK3 & 70 &, 50 & 7,95 & 2,5309 & 1,34570 \\
\hline LDR_BK3 & 70 & 68,54 & 100,70 & 88,0033 & 7,12300 \\
\hline CAR_BK3 & 70 & 10,80 & 29,47 & 17,7176 & 3,95662 \\
\hline NIM_BK3 & 70 & 3,60 & 14,00 & 6,8980 & 2,95265 \\
\hline OEOI_BK3 & 70 & 44,76 & 100,77 & 75,2229 & 16,33477 \\
\hline ROA_BK3 & 70 &,- 05 & 6,10 & 2,0983 & 1,13950 \\
\hline ROE_BK3 & 70 &,- 77 & 36,40 & 14,6893 & 7,36253 \\
\hline Valid N & 70 & & & & \\
\hline
\end{tabular}

Meanwhile, for BUKU 4 banks, have a LDR and CAR are approximately 70,37\% and ROA 3,37\% and ROE 26,44\% on average. The $16,51 \%$ respectively. Meanwhile for NIM and mean of NPL is 3,04\% and minimum value OEOI are $6,76 \%$ and $69,13 \%$ on average for is $0,40 \%$ and maximum $16,30 \%$. Average of BUKU 4 banks.

Tabel 2. Descriptive Statistic BUKU 4

\begin{tabular}{|c|c|c|c|c|c|}
\hline & $\mathbf{N}$ & Minimum & Maximum & Mean & Std. Deviation \\
\hline NPL_BK4 & 40 &, 40 & 16,30 & 3,0458 & 3,05569 \\
\hline LDR_BK4 & 40 & 40,30 & 88,54 & 70,3788 & 13,09306 \\
\hline CAR_BK4 & 40 & 12,70 & 25,30 & 16,5188 & 2,71488 \\
\hline NIM_BK4 & 40 & 4,70 & 11,16 & 6,7683 & 1,77568 \\
\hline OEOI_BK4 & 40 & 53,50 & 93,00 & 69,1335 & 8,48995 \\
\hline ROA_BK4 & 40 & ,90 & 5,15 & 3,3743 & 1,04130 \\
\hline ROE_BK4 & 40 & 8,00 & 43,83 & 26,4478 & 8,31890 \\
\hline Valid N & 40 & & & & \\
\hline
\end{tabular}

Empirical Results from Panel Data Analysis Other variable, OEOI have highly significant

Table 3 shows the T statistic using ROA negative impact on ROA, meanwhile CAR is and ROE as dependent variables on BUKU highly significant and positively on ROA. As 3 banks. NIM is highly significant and for the LDR there is no significant effect on positively on ROA and ROE. When, NPL have ROA and ROE. significant negative effect to ROA and ROE.

Tabel 3. Regression Statistic BUKU 3

\begin{tabular}{lccccc}
\hline & $\begin{array}{c}\text { Original } \\
\text { Sample (O) }\end{array}$ & $\begin{array}{c}\text { Sample } \\
\text { Mean (M) }\end{array}$ & $\begin{array}{c}\text { Standard } \\
\text { Deviation } \\
(\text { STDEV) }\end{array}$ & $\begin{array}{c}\text { Standard } \\
\text { Error } \\
(\text { STERR) }\end{array}$ & $\begin{array}{c}\text { T Statistics }(\mid \mathbf{O} / \\
\text { STERR|) }\end{array}$ \\
\hline OEOI -> ROA & $-0,227666$ & $-0,239297$ & 0,104514 & 0,104514 & $2,178334^{*}$ \\
OEOI -> ROE & $-0,188137$ & $-0,200329$ & 0,102196 & 0,102196 & 1,840931 \\
CAR -> ROA & 0,229655 & 0,201092 & 0,104881 & 0,104881 & $2,189667^{*}$ \\
CAR -> ROE & $-0,061248$ & $-0,092577$ & 0,109371 & 0,109371 & 0,560000 \\
LDR -> ROA & 0,057280 & 0,051989 & 0,078237 & 0,078237 & 0,732131 \\
LDR -> ROE & $-0,158769$ & $-0,159226$ & 0,093474 & 0,093474 & 1,698538 \\
NIM -> ROA & 0,448141 & 0,462443 & 0,090418 & 0,090418 & $4,956308^{*}$ \\
NIM -> ROE & 0,614504 & 0,626956 & 0,095633 & 0,095633 & $6,425626^{*}$ \\
NPL -> ROA & $-0,219602$ & $-0,230333$ & 0,078289 & 0,078289 & $2,805023^{*}$ \\
\hline
\end{tabular}




\begin{tabular}{lccccc}
\hline & $\begin{array}{c}\text { Original } \\
\text { Sample (O) }\end{array}$ & $\begin{array}{c}\text { Sample } \\
\text { Mean (M) }\end{array}$ & $\begin{array}{c}\text { Standard } \\
\text { Deviation } \\
\text { (STDEV) }\end{array}$ & $\begin{array}{c}\text { Standard } \\
\text { Error } \\
\text { (STERR) }\end{array}$ & $\begin{array}{c}\text { T Statistics }(\mid \mathbf{O} / \\
\text { STERR } \mid)\end{array}$ \\
\hline NPL -> ROE & $-0,207553$ & $-0,223139$ & 0,086223 & 0,086223 & $2,407174^{*}$ \\
$\mathrm{R}^{2}$ for ROA & & & $\mathbf{0 , 6 4 7 3 9 3}$ & & \\
$\mathrm{R}^{2}$ for ROE & & $\mathbf{0 , 5 5 4 9 8 9}$ & \\
\hline
\end{tabular}

Note : * Indicate Significant level of 5\% (T statistic $>1,96)$

Table 4 shows the T statistic using ROA and ROE as dependent variables on BUKU 4 banks. NIM is highly significant and positively on ROA and ROE. When, OEOI have significant negative effect to ROA and ROE.
Other variable, NPL have highly significant negative impact on ROA, meanwhile CAR and LDR are significant and positively to ROE on BUKU 4 banks.

Tabel 4. Regression Statistic BUKU 4

\begin{tabular}{llllll}
\hline & $\begin{array}{l}\text { Original } \\
\text { Sample }(\mathrm{O})\end{array}$ & $\begin{array}{l}\text { Sample Mean } \\
(\mathrm{M})\end{array}$ & $\begin{array}{l}\text { Standard } \\
\text { Deviation } \\
(\text { STDEV })\end{array}$ & $\begin{array}{l}\text { Standard Er- } \\
\text { ror (STERR) }\end{array}$ & $\begin{array}{l}\text { T Statistics }(\mid \mathrm{O} / \\
\text { STERR } \mid)\end{array}$ \\
\hline OEOI -> ROA & $-0,469941$ & $-0,479522$ & 0,124412 & 0,124412 & $3,777299^{*}$ \\
OEOI -> ROE & $-0,386745$ & $-0,386692$ & 0,188548 & 0,188548 & $2,051173^{*}$ \\
CAR -> ROA & 0,013936 & 0,001607 & 0,066060 & 0,066060 & 0,210957 \\
CAR -> ROE & $-0,233410$ & $-0,258767$ & 0,108911 & 0,108911 & $2,143121^{*}$ \\
LDR -> ROA & 0,072759 & 0,076442 & 0,048733 & 0,048733 & 1,493030 \\
LDR -> ROE & $-0,161385$ & $-0,169897$ & 0,082117 & 0,082117 & $1,965303^{*}$ \\
NIM -> ROA & 0,613070 & 0,615746 & 0,081974 & 0,081974 & $7,478857^{*}$ \\
NIM -> ROE & 0,658551 & 0,655428 & 0,083859 & 0,083859 & $7,853039^{*}$ \\
NPL -> ROA & $-0,257110$ & $-0,244607$ & 0,122575 & 0,122575 & $2,097576^{*}$ \\
NPL -> ROE & $-0,160509$ & $-0,160116$ & 0,163549 & 0,163549 & 0,981416 \\
R $^{2}$ for ROA & & & $\mathbf{0 , 9 0 4 8 7 3}$ & & \\
R $^{2}$ for ROE & & & $\mathbf{0 , 7 4 1 1 6 1}$ & & \\
\hline
\end{tabular}

Note : * Indicate Significant level of 5\% (T statistic $>1,96)$

\section{Discussion}

Profitability is an important criterion to measure the performance of banks, especially in the changing environment of banking (Alper and Anbar, 2011). This study examines the determinants of commercial bank profitability in Indonesia based on Commercial Bank Group of Business Activities (BUKU). The results shows that net interest margin (NIM) impact both on group BUKU 3 and BUKU 4 banks in Indonesia. NIM is a comparison between the percentage of interest to the total asset on the total earning assets (Riyadi, 2006:21). This ratio indicates the ability of the bank's net interest income resulted with placements earning assets. The larger this ratio the better the performance of the bank in generating interest income (Taswan, 2010:167). The larger the NIM achieved by a bank it will increase interest on the income earning assets managed by the bank in question, so that the profit of the bank (ROA and ROE) will increase. These findings support the research results from Sabir et.al (2012), Eng (2013).

For other variable that is Operating Expense to Operating Income ratio (OEOI) shows that if OEOI increase, it means efficiency decreases, then the profitability acquired the bank will decrease. This is because the level of efficiency of bank operations in effect on revenue or earning that are generated by the bank. If the operations are conducted efficiently (in this case the value of the ratio of OEOI is low) then the bank generated revenue is going up. In addition, the magnitude of the ratio of OEOI is also 
caused due to the high cost of funds collected and low interest income from cultivation of the funds. So when OEOI increase then it will be decrease the profitability. These findings support the research results from Haryanto (2016), Buchory (2015).

Credit is the dominant source of bank revenue that would affect the profitability of bank. Because of the highest revenue is reached from interest rate (Haryanto, 2016). In this research shows that NPL have significant negative effect to profitability, this condition means that the higher NPL, the lower profitability of the bank. These findings support the research results from Eng (2013), Ongore and Kusa (2013), Rotinsulu et.al (2015), Akhtar and Sadaqat (2011), Sabir et.al, (2012). Fulfillment of capital adequacy banks in Indonesia are based on PBI No. $15 / 12 / \mathrm{PBI} / 2013$ is based on the risk profile. The higher the Risk Weighted Assets, then the Capital of the banks should also be improved. BUKU 3 and BUKU 4 are group of banks with large capital, processing third-party funds and the largest credit issuer, so it has a fairly high risk profile. Banks with a high risk profile based on PBI No. 15/12/PBI/2013 required to have the CAR between $11 \%-13 \%$ and gradually continued to be promoted. This is done in order to strengthen the bank's capital so more resilient in the face of the crisis. The result shows that CAR has effect on ROA, but it has not significant effect on ROE in BUKU 3 banks. While CAR has effect on ROE, but it has not significant effect on ROA in BUKU 4 banks. As of for Loan to Deposit Ratio (LDR), in this research shows almost no impact on profitability. LDR only impact on ROE in BUKU 4 banks.

\section{CONCLUSION}

Based on the results, it is concluded that the partial, Net Interest Margin (NIM) has positive and significant effect on profitability both on BUKU 3 and BUKU 4 banks. Operating expenses to operating income (OEOI) and Non Performing Loan (NPL) has negative and significant effects to the profitability. Capital Adequacy Ratio (CAR) and Loan to Deposit Ratio (LDR) have various effect on profitability in BUKU 3 and BUKU 4 banks in Indonesia. Simultaneously that all of independent variable namely, NPL, LDR, CAR, NIM, and OEOI have significantly influence to profitability variable (ROA and ROE). The amount of the contribution or influence independent variables to ROA are $64,7 \%$ in BUKU 3 banks and $90,4 \%$ on BUKU 4 banks. Meanwhile contribution of independent variables to ROE are $55,4 \%$ in BUKU 3 banks and 74,1\% in BUKU 4 banks.

\section{REFERENCES}

Adeyinka, S., \& Olalekan, A. (2013). Capital Adequacy and Banks' Profitability: an Empirical Evidence From Nigeria. American International Journal of Contemporary Research, 3(10), 87-93.

Akhtar, M., Ali, K., \& Sadaqat, S. (2011). Factors Influencing the Profitability of Islamic Banks of Pakistan. International Research Journal of ..., 66(66), 1-8. Retrieved from http://joc.hcc.edu.pk/ faculty_publications/IRJFE_66_12.pdf

Alper, D., \& Anbar, A. (2011). Bank Specific and Macroeconomic Determinants of Commercial Bank Profitability: Empirical Evidence from Turkey. Business \& Economics Research Journal, 2 (2), 139-152. Retrieved from http : // search.ebscohost.com / login. aspx ?direct $=$ true $\&$ profile $=$ ehost\&scope $=$ site\&authtype $=$ crawler\&jrnl $=$ 13092448\&AN $=60823676 \& \mathrm{~h}=$ 3pyz1k9juw RV8hD6tim STmM0AA9 KN0vZXziY TPoLNA 3 vQ s OJZ / awa7yr9nfLN16JAQWO1O FIjLi2Z94RShImw $==\& \mathrm{crl}=\mathrm{c}$

Alamsah, Dedi. (2013). Pengaruh Tingkat Kecukupan Modal, Likuiditas, dan Non Performing Loan Terhadap Profitabilitas pada Bank Umum yang Terdaftar di 
Bursa Efek Indonesia Periode 20082012. Jurnal Akuntansi dan Manajemen Esa Unggul. Vol. 1 No. 1.(242-268).

Almadany, Khairunnisa. (2014). Pengaruh Loan to DepositRatio, Biaya Operasional Per Pendapatan Operasional dan Net Interest Margin Terhadap Profitabilitas Perusahaan Perbankan yang Terdaftar di Bursa Efek Indonesia. Jurnal Riset Akuntansi \& Bisnis 12.2

Bank Indonesia. (2013). PBI No. 15/12/ PBI/2013 Subject : Capital Adequacy on Commercial Bank

Bank Indonesia. (2012). PBI No. 14/26/ $\mathrm{PBI} / 2012$ Subject : Business activities and office network based on core capital of the Bank

Buchory,H.A.(2015). Banking intermediation, operational efficiency and credit risk in the banking profitability, 7(2), 57-63.

Eng, T. S. (2013). Pengaruh NIM, BOPO, LDR, NPL \& CAR Terhadap ROA Bank Internasional dan Bank Nasional Go Public Periode 2007-2011. Jurnal Dinamika Manajemen Vol. 1 No.3 JuliSeptember 2013, 1(3), 153-168.

Haryanto, S. (2016). Profitability Identification of National Banking Through Credit, Capital, Capital Structure, Efficiency, And Risk Level, 7(57), 11-21.

Latan, H., \& Ghozali, I. (2012). Partial Least Squares Konsep, Teknik dan Aplikasi Menggunakan Program SmartPLS 2.0 M3. Badan Penerbit Universitas Diponegoro, Semarang.

Ongore, V. O., \& Kusa, G. B. (2013). Determinants of Financial Performance of Commercial Banks in Kenya. International Journal of Economics and Financial Issues, 3(1), 237-252. Retrieved from www.econjournals.com

Republik Indonesia. (1998). Law No. 10/1998 about Banking. Jakarta

Riyadi, Selamet. 2006. Banking Assets and Liability Management (Edisi Ketiga). Lembaga Penerbit Fakultas Ekonomi Universitas Indonesia. Jakarta

Rotinsulu, D. P., Kindangen, P., \& Pandowo, M. (2015). the Analyze of Risk-Based Bank Rating Method on Bank'S Profitability in State-Owned Banks. Jurnal Riset Ekonomi, Manajemen, Bisnis Dan Akuntansi, 3(1), 95-106.

Sabir, M., Ali, M., \& Habbe, A. H. (2012). Pengaruh Rasio Kesehatan Bank Terhadap Kinerja Keuangan Bank Umum Syariah dan Bank Konvensional di Indonesia. Jurnal Analisis, 1(1), 7986.

Suhardi dan Darus Altin. (2013). Analisis Kinerja Keuangan Bank BPR Konvensional di Indonesia Periode 2009 Sampai 2012. Pekbis Jurnal Vol. 5 No. 2 (101-110)

Taswan, 2010. Manajemen Perbankan Konsep, Teknis \& Aplikasi. Penerbit UPP STIM YKPN Yogyakarta.

Valentina Flamini, Calvin McDonald, and L. S. (2013). The Determinants of Commercial Bank Profitability in SubSaharan Africa. International Journal of Economics and Finance, 5(9), 134-148. http://doi.org/10.5539/ijef.v5n9p134 